\title{
Assay of serum fibrin degradation products by agglutination-inhibition of coated erythrocytes
}

P. C. DAS

From the Regional Transfusion Centre and Blood Products Unit, Royal Infirmary, Edinburgh

SYNOPSIS An immunological method for detecting fibrin degradation products by tanned cells agglutination has been standardized. The effects of different variables, such as cell concentration, $p \mathrm{H}$, and length of incubation, and the specificity of the reaction, are described. The method is compared with other immunological techniques.

Proteolysis of fibrinogen and fibrin by plasmin results in the elaboration of polypeptide fragments known as fibrinogen or fibrin degradation products. Two of the fragments, $D$ and $E$, comprising about $70 \%$ of total digests (Niléhn, 1967) share an immunological identity with the parent fibrinogen (Nussenzweig, Seligmann, and Grabar, 1961), and can be detected by immunological techniques.

Boyden's (1951) technique, in which tanned red cells may be coated with human fibrinogen (Das, 1970), can be adopted as a haemagglutination inhibition reaction for detecting circulating fibrin degradation products (Fox, Wide, Killander, and Gemzell, 1965; Merskey, Kleiner, and Johnson, 1966). This assay has been successfully applied for measuring serum fibrin degradation products in normal subjects (Das, Allan, Woodfield, and Cash, 1967), in uterine arterial and venous blood (Mackay, Das, Myerscough, and Cash, 1967), in normal pregnancy (Woodfieid, Cole, Allan, and Cash, 1968), and in cirrhosis (Das and Cash, 1969).

The present communication describes the standardization of this assay and also compares its sensitivity with other immunological techniques such as the Ouchterlony immunodiffusion (Ouchterlony, 1962), immunoelectrophoresis (Scheidégger, 1955), comparative immunoelectrophoresis (Niléhn and Nilsson, 1964), and antigenantibody crossed electrophoresis (Laurell, 1966).

\section{Materials and Methods}

1 Tanned sheep red cells coated with human fibrinogen (sensitized sheep red cells) are prepared according to the method of Das (1969).

2 Purified human fibrinogen $(97 \%$ clottable, Kabi Pharmaceuticals Ltd, Stockholm) is used as a reference standard.

3 Diluting fluid consisting of citrate-phosphate buffer (Das, 1970), pH 6.4, containing 0.4\% absorbed horse serum and $1 \mathrm{mg} / \mathrm{ml}$ sodiumazide was used routinely as a diluent except in those experiments where the effect of $p \mathrm{H}$ was investigated by the use of an appropriate buffer. 4 Rabbit anti-fibrinogen serum (Hoechst Pharmaceuticals Ltd, Germany) was diluted 1:500 in this diluting fluid and stored at $-40^{\circ} \mathrm{C}$; further dilutions were made from this stock solution.

\section{PREPARATION OF SPECIMEN}

\section{Serum}

Five $\mathrm{ml}$ blood was collected in test tubes containing 500 Kallikrein inactivator (KI) units of Trasylol (Bayer, Germany) and incubated at $37^{\circ} \mathrm{C}$ for four hours; the serum was separated by centrifugation at $2000 \mathrm{~g}$ for 10 minutes. The test serum was mixed with $1 / 10$ of its volume Received for publication 28 August 1969. 
of thrombin (100 units $/ \mathrm{ml})$, re-incubated at $37^{\circ} \mathrm{C}$ for one hour, and then centrifuged: this procedure removed any residual fibrinogen.

\section{Absorption of serum}

All serum samples were absorbed for 12 hours at $4^{\circ} \mathrm{C}$ with 1 volume of washed packed normal red cells to 2 volumes of test serum and either assayed immediately or stored at $-40^{\circ} \mathrm{C}$.

\section{INHIBITORY TITRE TEST}

Experiments were performed to investigate the ability of standard human fibrinogen solutions to inhibit the haemagglutination reaction of sensitized sheep red cells at different concentrations of an antifibrinogen serum; the optimum dilution of antiserum to be used in the inhibition reaction for the fibrin degradation products immunoassay was then calculated.

PERFORMANCE OF ASSAY OF SERUM FIBRIN DEGRADATION PRODUCTS A 'microtitre kit' (Cook Engineering Co., USA) was used for the performance of the test which has been described in detail elsewhere (Woodfield et al, 1968). Haemagglutination inhibition was recorded as complete (-), weak agglutination $( \pm)$, or frank agglutination $(+)$. Estimation of fibrin degradation products for each test sample were calculated in the following way:

Fibrin degradation products $(\mu \mathrm{g} / \mathrm{ml})=$ Fibrinogen concentration of standard

$\times \frac{\text { endpoint of test }}{\text { endpoint of standard }}$.

Each test was performed using two dilutions of antisera $(1: 5,000$ and $1: 10,000)$ simultaneously and paralleled by dilutions of at least two standard human fibrinogen solutions, the mean endpoints of each test and standard being taken. Positive and negative controls were included in each plate.

\section{Results}

Two possible sources of error in endpoint reading are (1) the presence of a cold agglutinin, and (2) the incomplete absorption of non-specific agglutinins. The former can be checked by keeping the plates for 30 to 45 minutes at room temperature before reading. The latter can be avoided by pre-absorption of the samples with normal sheep red cells. Haemolysis occurring in the samples during absorption can be prevented by the addition of EDTA $(2 \mathrm{mg} / \mathrm{ml})$ to the test serum, or samples can be absorbed with sheep red cell stroma.

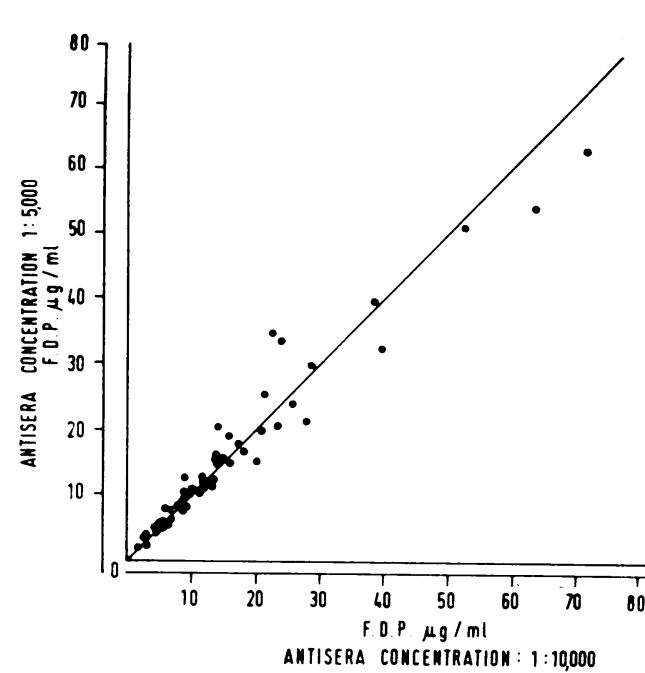

Fig. 1 Comparison of serum fibrin degradation product levels obtained by performing tests at two antisera concentrations.

\section{Sensitivity, Precision, and Reproducibility}

SENSITIVITY AND PRECISION

The inhibition titre of standard fibrinoge increased as more diluted antiserum was usech The sensitivity of the assay system, define as the smallest quantity of antigen required to inhibit the reaction, is improved by increasing the dilution of antiserum. However, when concentrated amount of antiserum is used in system in which measurement depends on an endpoint reading, the difference in cell pattern is more distinct and precision therefore greatero In practice, the sensitivity and precision of the assay system for fibrin degradation product 8 was anticipated by undertaking preliminar灭 tests, and antifibrinogen concentrations of $1: 5,000$ and 1:10,000 were adopted routinely in this immunoassay.

VARIATION IN THE ASSAY

Multiple aliquots of two different standard fibrinogen solutions were assayed at two antiser dilutions. Results showed that 75-80\% endpoint appeared at the same antigen concentration.

Possibly the largest variable factor is erroro in antigen dilution. However, precision can be improved either by carrying out parallel assays at different antiserum concentrations, or bD repeating assays and calculating the mean value

\section{REPRODUCI B I L I T Y}

Results of serum fibrin degradation producō concentrations are compared in Fig. 1; the 


\begin{tabular}{|c|c|c|c|c|}
\hline \multirow[t]{2}{*}{$\mathrm{p} H$} & \multicolumn{2}{|c|}{ Standard Fibrinogen ( $80 \mathrm{mg} \%$ ) } & \multicolumn{2}{|c|}{ Serum Sample } \\
\hline & $\begin{array}{l}\text { Inhibition } \\
\text { Titre }\end{array}$ & $\begin{array}{l}\text { Quantity at } \\
\text { Endpoints }(\mu \mathrm{g} / \mathrm{ml})\end{array}$ & $\begin{array}{l}\text { Inhibition } \\
\text { Titre }\end{array}$ & $\begin{array}{l}\text { Quantity at } \\
\text { Endpoints }(\mu \mathrm{g} / \mathrm{ml})\end{array}$ \\
\hline $\begin{array}{l}5 \cdot 0 \\
6 \cdot 0 \\
6.4 \\
7 \cdot 2 \\
7 \cdot 6 \\
8.0\end{array}$ & $\begin{array}{l}1 / 600 \\
1 / 600 \\
1 / 600 \\
1 / 600 \\
1 / 600 \\
1 / 600\end{array}$ & $\begin{array}{l}1.4 \\
1.4 \\
1.4 \\
1.4 \\
1.4 \\
1.4\end{array}$ & $\begin{array}{l}1 / 16 \\
1 / 16 \\
1 / 16 \\
1 / 16 \\
1 / 16 \\
1 / 16\end{array}$ & $\begin{array}{l}22 \cdot 4 \\
22 \cdot 4 \\
22 \cdot 4 \\
22 \cdot 4 \\
22 \cdot 4 \\
22 \cdot 4\end{array}$ \\
\hline
\end{tabular}

Table I Effect of $p \mathrm{H}$ on haemagglutination inhibition

standard error, analysed from duplicate observations, was $7 \cdot 4 \%$. Good agreement was obtained between the values obtained in two independent test systems $(1: 5,000$, mean $13 \cdot 13$ $\mu \mathrm{g} / \mathrm{ml} ; 1: 10,000$, mean $13.11 \mu \mathrm{g} / \mathrm{ml} ; \mathrm{r}=0.98$, $P<0.001$ ), and significant differences between the individual results were not observed $(t=$ $0 \cdot 164)$.

\section{VAR I A B ILITY}

The presence of fibrinolytic inhibitor in the sample Trasylol, a potent inhibitor of fibrinolysis, can be used to avoid the generation in vitro of fibrin degradation products without vitiating the test system. Of four specimens without Trasylol, three showed an increased haemagglutination inhibition titre and more fibrin degradation products than comparable samples containing the inhibitor.

Concentrations of sensitized sheep red cells Parallel assays, differing only in the concentration of sensitized sheep red cells $(2 \cdot 0-3 \cdot 5 \%)$ in the final test system, were performed. Results showed $c$ an increase in inhibition proportional to the cell $\stackrel{\varrho}{=}$ concentration.

\section{Effect of $\mathrm{pH}$}

When the assay was performed at different $\Rightarrow$ levels of $p \mathrm{H}(5 \cdot 0-8 \cdot 0)$, neither inhibition nor the quantities of fibrin degradation products detected in the serum samples were significantly affected (Table I).

\section{Length of incubation}

Tests were set up for the inhibition reaction and sensitized sheep red cells were added afterperiods of time varying from one to six hours. $\vec{\omega}$ Results summarized in Fig. 2 showed that titres? for both standard and test samples increased in proportion to the time of incubation. This did notw affect measurement but the finding that the sensitivity of the system could be increasedo in this way has a practical value.

\section{Specificity}

The specificity of the assay was studied using 1:5,000 antiserum; the results demonstrated that there was no inhibition by purified humam albumin and $\gamma$-globulin. Reagents used in the tes system, such as Trasylol, Ca-thrombin, or EDTA caused no inhibition, neither did the addition of a supernatant obtained by the incubation at $37^{\circ} \mathrm{C}$ for 30 minutes of purified fibrinogen $\overrightarrow{\overrightarrow{0}}$ with thrombin in the presence of Trasylol (Table II).

In a second series of experiments plasma; human fibrinogen, and their clots were incubate
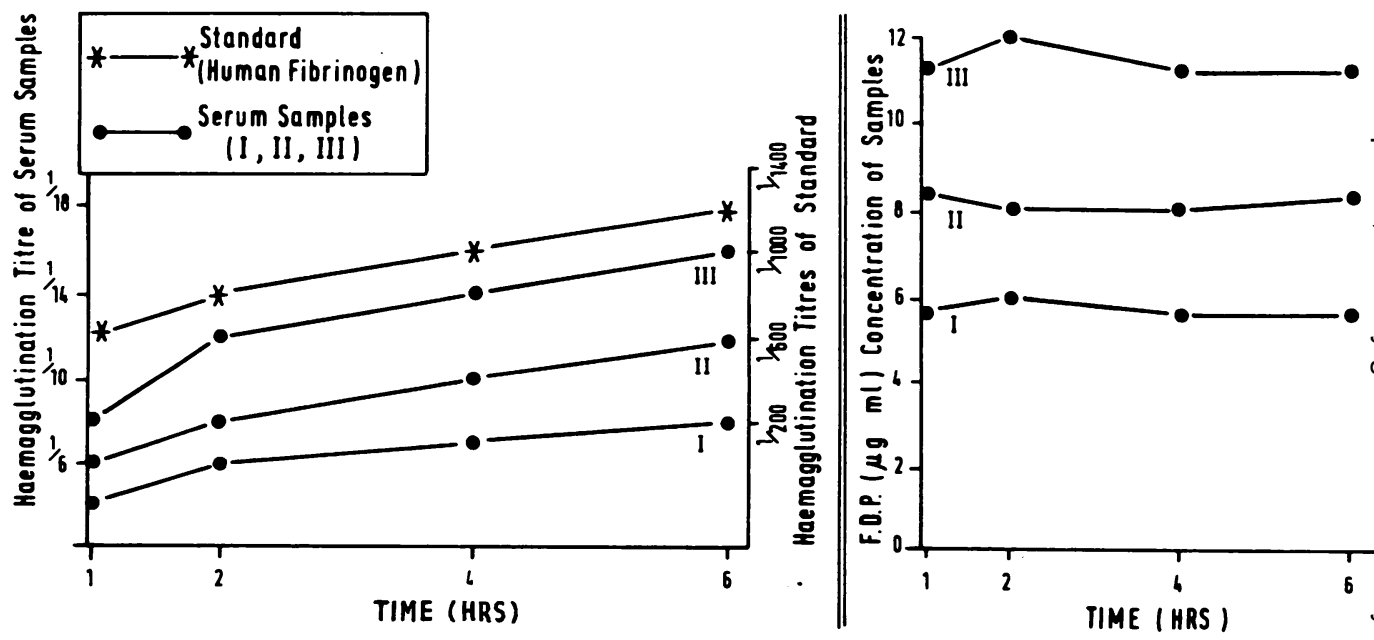

Fig. 2 Effect of increasing incubation time on fibrin degradation product (FDP) assay by haemagglutination inhibition presented as haemagglutination inhibition titre (left) and $\mu \mathrm{g} / \mathrm{ml}$ (right). 


\begin{tabular}{|c|c|c|}
\hline No. & Materials & Results \\
\hline 1 & Trasylol (5,000 KI units/ml) & No inhibition \\
\hline 2 & Ca-thrombin (100 units/ml) & No inhibition \\
\hline 3 & Urokinase $(5,000$ units $/ \mathrm{ml})$ & No inhibition \\
\hline 4 & Human albumin $(500 \cdot \mathrm{mg} / 100 \mathrm{ml})$ & No inhibition \\
\hline 5 & Human gamma globulin $(50 \mathrm{mg} / 100 \mathrm{ml})$ & No inhibition \\
\hline 6 & EDTA $(2 \mathrm{mg} / \mathrm{ml})$ & No inhibition \\
\hline 7 & $\begin{array}{l}\text { Supernatant obtained after incubation at } 37^{\circ} \mathrm{C} \text { for } 30 \\
\text { minutes of purified fibrinogen with thrombin in the presence } \\
\text { of Trasylol }\end{array}$ & No inhibition \\
\hline \multirow[t]{2}{*}{8} & $\begin{array}{l}\text { Plasma clots incubated with urokinase and plasmin for } 12 \\
\text { hours }\end{array}$ & \\
\hline & $\begin{array}{ll}\text { Supernatant } & (\text { a) } \text { with thrombin } \\
& (b) \text { without thrombin }\end{array}$ & $\begin{array}{l}\text { Inhibition } \\
\text { Inhibition }\end{array}$ \\
\hline \multirow[t]{2}{*}{9} & $\begin{array}{l}\text { Purified human fibrinogen incubated with urokinase and } \\
\text { plasmin for } 12 \text { hours:- }\end{array}$ & \\
\hline & $\begin{array}{ll}\text { Supernatant } & \text { (a) with thrombin } \\
& \text { (b) without thrombin }\end{array}$ & $\begin{array}{l}\text { Inhibition } \\
\text { Inhibition }\end{array}$ \\
\hline
\end{tabular}

Table II Specificity of the haemagglutination reaction

with plasmin (Kabi Pharmaceuticals) and urokinase (Leo Pharmaceuticals, Denmark). After complete digestion of the substrate, aliquots were tested before and after the addition of thrombin (100 units $/ \mathrm{ml})$. Results showed that haemagglutination was inhibited by the products of fibrinolysis and fibrinogenolysis (Table II).

A third series of experiments was designed to study the effect of heparin (Evans Ltd, UK) in the assay system and indicated that heparin masks the presence of fibrin degradation products

\section{Comparison of Haemagglutination Inhibition Immunoassay with Other Immunological Techniques}

Some serum samples with a high content of fibrin degradation products showed two precipitation lines on Ouchterlony plates; single lines usually appeared with lower concentrations of split products. Good separation of fibrin degradation products was obtained by immunoelectrophoresis although low concentrations frequently failed to show precipitin arcs; with higher concentrations, two arcs resembling $\mathrm{D}$ and $\mathrm{E}$ fragments were occasionally visible. The use of comparative immunoelectrophoresis allows the serological identification of precipitins and precipitinogens in addition to clarifying their mobility by combining immunoelectrophoresis and gel diffusion.

Table III shows the results of 20 serum samples in which the concentration of fibrin degradation products was measured by haemagglutination inhibition assay. In these test systems the sensitivity of Ouchterlony immunodiffusion and comparative immunoelectrophoresis are found to be similar $(10-20 \mu \mathrm{g} / \mathrm{ml})$. On the other hand immunoelectrophoresis was found to be less sensitive. A precipitin arc of $13 \mathrm{~mm}$ was obtained from a serum sample containing $56 \mu \mathrm{g} / \mathrm{ml}$ fibrin degradation products on crossed electrophoresis; the length of the precipitin arc was proportional

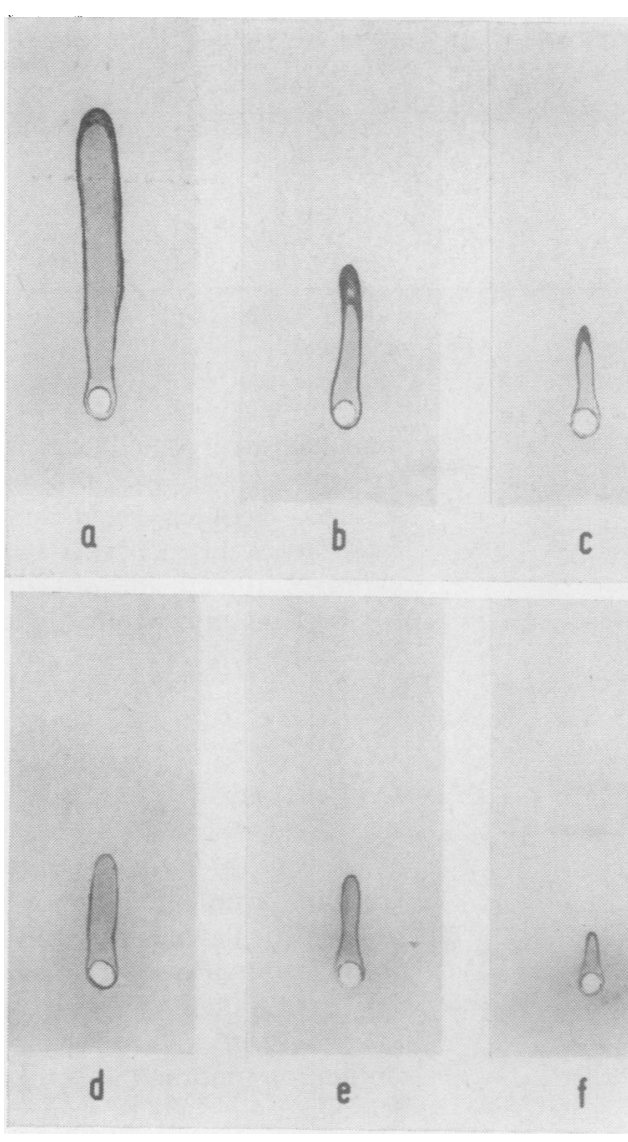

Fig. 3 Crossed electrophoresis of serum albumin and serum fibrin degradation products. Slides $\mathrm{a}, \mathrm{b}$, and c contain neat $(2.5 \mathrm{~g} \%), \frac{1}{2}$, and $\frac{1}{4}$ solutions of albumin respectively; slides $\mathrm{d}, \mathrm{e}$, and $\mathrm{f}$ contain neat $(56 \mu \mathrm{g} / \mathrm{ml}), \frac{1}{2}$, and $\frac{1}{4}$ dilutions of serum fibrin degradation products respectively.

to the amount of fibrin degradation products present in a manner similar to that obtained using standard albumin solution (Fig. 3).

\section{Comments}

The present investigation shows that haemagglutination inhibition immunoassay is $10-\frac{20}{0}$ times more sensitive than the conventiona 1 immunological techniques, thus permitting the measurement of small quantities of fibron

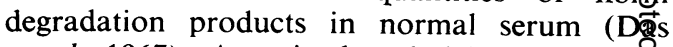
et al, 1967). A trained technician can assi ify 25 samples per day. Samples may be deep frozen if necessary (Das et al, 1967), and Merskey, Johnson, Kleiner, and Wohl (1967) have shoon that storage for six months is quite safe. Although a little laborious at first and demanding rigoreis control, the technique is rapid, simple, a $\overline{\text { hd }}$ economical. 


\begin{tabular}{|c|c|c|c|c|c|c|}
\hline \multirow[t]{3}{*}{ Method } & \multicolumn{5}{|c|}{ Fibrin Degradation Products } & \multirow{3}{*}{$\begin{array}{l}\text { Total No. } \\
\text { of Samples }\end{array}$} \\
\hline & \multicolumn{5}{|c|}{ Number of Samples Giving Positive Reaction with } & \\
\hline & $5 \mu \mathrm{g} / \mathrm{ml}$ & $10 \mathrm{\mu g} / \mathrm{ml}$ & $25 \mu \mathrm{g} / \mathrm{ml}$ & $50 \mu \mathrm{g} / \mathrm{ml}$ & $>100 \mu \mathrm{g} / \mathrm{ml}$ & \\
\hline $\begin{array}{l}\text { Haemagglutination } \\
\text { inhibition } \\
\text { immunoassay }\end{array}$ & 7 & 4 & 4 & 3 & 2 & 20 \\
\hline Ouchterlony & 0 & 3 & 4 & 3 & 2 & 12 \\
\hline $\begin{array}{l}\text { Comparative } \\
\text { immunoelectro- } \\
\text { phoresis }\end{array}$ & $\mathbf{0}$ & 3 & 3 & 3 & 2 & 11 \\
\hline $\begin{array}{l}\text { Immunoelectro- } \\
\text { phoresis }\end{array}$ & 0 & $\mathbf{0}$ & 1 & 2 & 2 & 5 \\
\hline
\end{tabular}

Table III Comparison of haemagglutination inhibition immunoassay with Ouchterlony, immunoelectrophoresis, and comparative immunoelectrophoresis techniques

Increased inhibition after prolonged incubation of the antigen with antibody is believed to be due to the progressive aggregation of antigenantibody complexes and a consequent reduction in their ability to coat sensitized cells (Fulthorpe, 1959). This observation can be put to practical use by improving the sensitivity of the test system, this being less when dilute antisera are used. However, provided the standard and the unknown sera are treated identically, the length of incubation, change of cell concentration, or $p \mathrm{H}$ of the test medium will not affect the results significantly.

Heparin in the test system interferes with the reaction by showing an apparent decrease in the amount of fibrin degradation products; this is believed to be a manifestation of inhibition by a polyanion, having a high affinity for fibrinogen, on the interaction of fibrinogen and its antibody (Murakami, 1965).

It is of interest to note the observation by McLaughlin (1968) that in vitro early fibrinogen degradation products produced by plasmin form a complex with chylomicrons: lipaemic serum may interfere with the immunological techniques and further study is required.

It is possible that an assay system for measuring fibrin degradation products in serum may detect only a proportion of the total amount, since it is known that some products are incorporated in the clot structure (Bang, Fletcher, Alkjaersig, and Sherry, 1962; Latallo, Budzyński, Lipiński, and Kowalski, 1964). Moreover, the haemagglutination method gives no information on the heterogeneous molecular size and physicochemical characteristics of fibrin degradation products. For this reason it seems that other methods of comparable sensitivity, but greater specificity and precision, must be developed, perhaps by utilizing preliminary separation procedures. Although, in the present work antigen-antibody crossed electrophoresis was carried out on only a limited scale, similar work by Laurell (1965 and 1966) seems to be encouraging and, for preliminary separation, the use of acrylamide gel (Fisher, Fletcher, $c$ Alkjaersig, and Sherry, 1967) may be justified.

I am indebted to Dr R. A. Cumming, and Dr J. D. D Cash, South-East Scotland Blood Transfusion Centre, for excellent laboratory facilities, and Dr I. M. Riding for her expert advice. This work $\vec{F}$ is supported by the Scottish National Blood Transfusion Association and the Scottish Hospital Endowment Research Trust.

References (1962). Pathogenesis of the coagulation defect developing $\vec{O}$ during pathological plasma proteolytic ('fibrinolytic')states. III. Demonstration of abnormal clot structure by $\vec{\omega}$ electron microscopy. J. clin. Invest., 41, 935-948.

Boyden, S. V. (1951). The adsorption of proteins on erythrocytes treated with tannic acid and subsequent hemagglutination by antiprotein sera. J. exp. Med., 93, 107-120.

Das, P. C. (1970). Investigations and preparation of fibrinogen $\omega$ coated tanned sheep red cells. J. clin. Path., 23, 149-155. is

Das, P. C., Allan, A. G. E., Woodfield, D. G., and Cash, J. D. N (1967). Fibrin degradation products in sera of normal subjects. Brit. med.J., 4, 718-720.

Das, P. C., and Cash, J. D. (1969). Fibrinolysis at rest and after음 exercise in hepatic cirrhosis. Brit. J. Haemat., 17, 431-443. -

Fisher, S., Fletcher, A. P., Alkjaersig, N., and Sherry, S. (1967). Immunoelectrophoretic characterization of plasma fibrinogen derivatives in patients with pathological plasma $<$ proteolysis. J. Lab. clin. Med., 70, 903-922.

Fox, F. J., Jr., Wide, L., Killander, J., and Gemzell, C. (1965). Determination of fibrinogen and fibrinolysis products $\bigcirc$ in human plasma by an immunochemical method. Scand." J. clin. Lab. Invest., 17, 341-348.

Fulthorpe, A. J. (1959). Factors influencing hemagglutination tests with tetanus antitoxin. Immunology, 2, 104-111.

Latallo, Z. S., Budzyński, A. Z., Lipiński, B., and Kowalski, E.⿳亠丷厂 (1964). Inhibition of thrombin and of fibrin polymerization, two activities derived from plasma-digested fibrino- $\mathbb{D}$ gen. Nature (Lond.), 203, 1184-1185.

Laurell, C. B. (1965). Antigen-antibody crossed electrophoresis. Analyt. Biochem., 10, 358-361.

Laurell, C. B. (1966). Quantitative estimation of proteins by electrophoresis in agarose gel containing antibodies. $\vec{乛}$ Analyt. Biochem., 15, 45-52.

Mackay, A. V. P., Das, P. C., Myerscough, P. R., and Cash, J. D. (1967). Fibrinolytic components of human uterine arteriat and venous blood. J. clin. Path., 20, 227-230.

McLaughlin, M. (1968). Studies on fibrinolysis and plasma lipidi with special reference to tryglycerides. M.Sc. Thesis. 3 University of Edinburgh.

Merskey, C., Kleiner, G. J., and Johnson, A. J. (1966). Quantitat-Ō ive estimation of split products of fibrinogen in human serum, relation to diagnosis and treatment. Blood, 28 , 1-18.

Merskey, C., Johnson, A. J., Kleiner, G. J., and Wohl, H. (1967). The defibrination syndrome: clinical features and lab-C oratory diagnosis. Brit.J. Haemat., 13, 528-549.

Murakami, M. (1965). An immunological method for demonstrating fibrin or fibrinogen degradation products in the circulating blood. (Japanese.) Acta haemat. Jap., 28, N 341-344.

Niléhn, J. E. (1967). Separation and estimation of split 'products' of fibrinogen and fibrin in human serum. Thrombos. Diathes. haemorrh. (Stuttg.), 18, 487-498.

Niléhn, J. E., and Nilsson, I. M. (1964). Demonstration ofo fibrinolytic split products in human serum by an immunological method in spontaneous and induced fibrinolytic states. Scand. J. Haemat., 1, 313-330.

Nussenzweig, V., Seligmann, M., and Grabar, P. (1961). Les produits de dégradation du fibrinogène humain par las $\bar{T}$ plasmine. Ann. Inst. Pasteur, 100, 490-508.

Ouchterlony, O. (1962). Diffusion-in-gel methods for immunological analysis. II. Progress in Allergy, 6. Edited by P. Kallos and B. H. Waksman, pp. 30-154. Karger, Basel

Scheidegger, J. J. (1955). Une micro-méthode de l'immuno-g électrophorèse. Int. Arch. Allergy, 7, 103-110.

Wide, L. (1962). An immunological method for the assay of huran chorionic gonadotrophin. Acta endocr. (kbhl.) 41, suppl. 70.

Woodfield, D. G., Cole, S. K., Allan, A. G. E., and Cash, J. D̄̄ (1968). Serum fibrin degradation products throughout normal pregnancy. Brit. med.J.. 4, 665-658. 